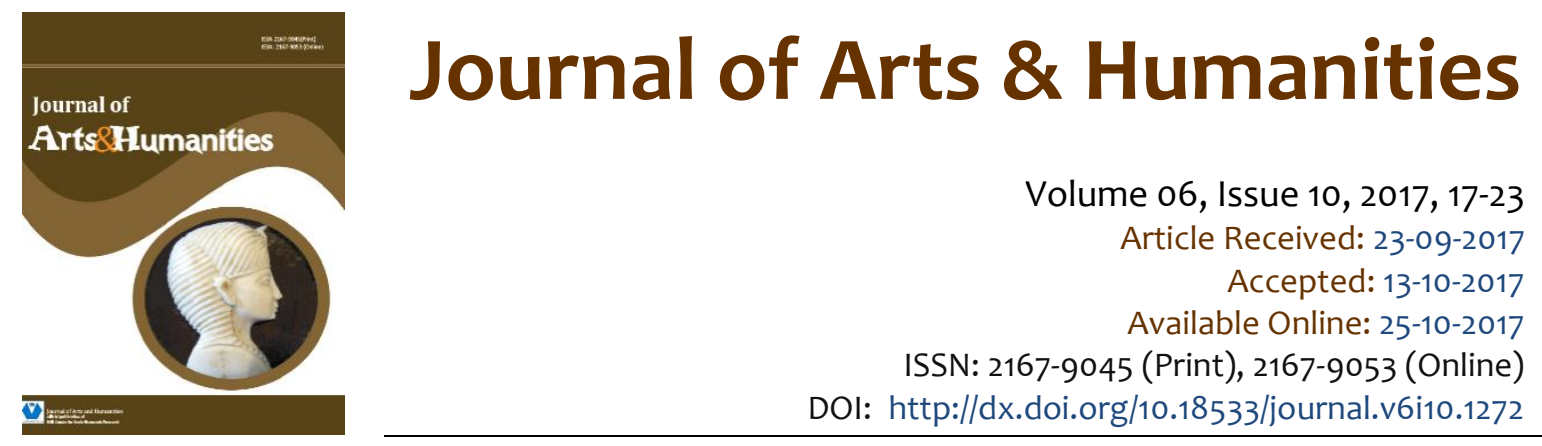

\title{
In Defense of American Drama
}

\author{
Salim E. Al-Ibia ${ }^{1}$
}

\begin{abstract}
A colleague of mine claimed that he read somewhere that a former secretary of the Swedish Institute, which awards the Nobel prizes - commented that American writers were less likely to win the award since their work was isolated and not representative of universal experience. But Eugene O'Neil and other American playwrights were named Nobel Laureates. Thus, I write this article in defense of the universality of American drama. Beginning with a discussion of what might be regarded as defining elements of universality as it has been rendered in literature, and more specifically how it operates to make drama relevant and significant for world literature, I examine the work of prominent American playwrights as Arthur Miller, O'Neil, Tennessee Williams, Susan Glaspell, and Edward Albee. I argue that their work establishes a precedent for American drama as a particularly representative expression of aspects of a universal human condition. I relate their work to universal contexts. I shed light on the historical background of some of the plays discussed to argue that American writers are no less talented than other international playwrights who dramatized some historical precedents in their work and their plays present no less universal aspects.
\end{abstract}

Keywords: American Drama, Human Condition, The Canon, Universality.

This is an open access article under Creative Commons Attribution 4.0 License.

\section{Introduction: Universality in literature}

The importance of universality in drama and literature might be related toobvious reasons. It tells how much a play would appeal to its audience across the world since universalityrefers to forms of arts that appeal to everyone in different places and times. It describes the extent to which playwrights are aware of world major events and the larger context of various cultures. Thus, it enhances a playwright's presence in the context of world literature and drama. It shows the extent to which his work is in dialogue with their international peers. The theme of universality is infrequently mentioned in association to American drama and therefore, I think, it is worth investigating.

Generally speaking, universality is an aspect that goes beyond historical and cultural boundaries. If we look up the meaning of the word "universal", the dictionary would suggest several meanings. It might mean "relating to whole world", "relating to universe", "relating to those in

\footnotetext{
${ }^{1}$ Assistant Professor, English Department, Al al-Bayt University, Mafraq, Jordan 25113. Email: ibiasa@yahoo.com
} 
particular group: relating to, affecting, or including everyone in a group or situation", "used by everyone: used or understood by everyone", "applicable to all: applicable to all situations or purposes", "present everywhere: present or prevalent everywhere" and "affirming or denying every member: relating to a proposition that is true or false of every member of a class or group" (Oxford Dictionary) extra... All these meanings suggest that when somebody says something is universal, then, it might exist in different cultures and times. C. G. Jung refers to universality of his "Archetypes" in the same sense when he says archetypes can be archetypes only when they are accepted by people as a whole and not by individuals of a particular group (Manheim, 1959, p. 104).

In literature, universality is closely associated with what is called the canon; a term coined by T.S. Elliot to refer to the list of great works of literature. According to Elliot (1964), What produces the greatness in a work of art is not the emotions aroused by the text. But rather, it is the nature of the artistic devices through which they are presented. In my estimation, the authorof aliterary text is responsible for creating unique devises to present his work in away that appeals to people in different cultures and times to immortalize his work or to make it part of the canon.It seems to me that the author or the playwright should follow some traditional methods while portraying his work so he can fit into the canon as a result. Such literary traditions are what create universality in the first place. These traditions become more or less like the basic elements to evaluate the greatness of work on the one hand, and its universality on the other.

Universality, then, is a distinct feature of any great piece of literature. It seems to me that literary works are evaluated according to the extent to which they appeal to the human condition across cultures and times. Thus, they become universally accepted as part of the canon.Universality is what introduced the works ofWilliam Shakespeare or DanteAlighieri as part of the canon because they worked hard to appeal or present the reality of human condition. For hundred of years their work has appealed to critics and readersacross the globe. Theirreputationcomes as a natural result of their success to create unique characters that we all connect with as we read their work. S. Park (2009)contends that Dantesucceeds to createuniversal rather than European appeal through presenting human reality in theuniversal dimension; the "really universally universal man rather than what Husserl has called the European man in crisis" (p. 177).

The real human condition might be also associated with history since history is supposedly related to true human events of which the whole world is aware. Universality therefore might be created through dramatizing some real historical incidents. In fact, dramatizing historical events was always one of the favorite topics approached by different playwrights in different periods of time. Again and again, Shakespeare might be the finest example among the playwrights who Knows how to dramatize historical incidents and traditional stories. Hamlet's plot is based on a story that comes from the European heritage. Shakespeare's Richard III, Henry VII and Henry VIII are all based on history. Another modern example is Bernard Shaw's Caesar and Cleopatra, which is also based on history.

\section{Discussion}

Arthur Miller's, The Crucible, makes an ideal example of the kind of American play that has deep universal and historical elements. According to Christopher Bigsby (1995),the play dramatizes a real historical event that happened in a small town in eastern Massachusetts in 1692 (p. vii). The central theme of religious forgiveness in the play can be considered as a universal aspect of the play since the religious theme of forgiveness can be traced back to medieval drama (miracle plays) and Renaissance drama. The Crucible is also one of a few modern tragedies in which the plot is portrayed on the Greek traditions. In fact, the plot is not the only literary element that can be associated with the Greek traditions in the play since this tragedy is also among a few modern plays in which we have a real tragic hero rather than a protagonist.

There is no doubt that the crucible's plot was inspired directly from a real historical story. In 1692, "nineteen men and woman and two dongs were convicted and hanged for witchcraft" in a small village in eastern Massachusetts (Parker 2002, p. 81). The bodies of those people were buried in shallow graves but their names remain with us until this day at least because of Arthur miller's The Crucible. According to Christopher Bigsby (1995), Arthur Miller first encountered the story of Salem and its witches while a student at the University of Michigan (viii). The idea of dramatizing Salem's story came to Miller's mind after he was accused with being a communist by the American government around 
1949. Arthur Miller himself made this connection when he stated that "At first I rejected the idea of a play on the subject. But over weeks, a living connection between myself and Salem, and between Salem and Washington, was made in my mind" (p. $\mathrm{x}$ ).

However, Miller's play is not "history in the sense in which the word is used by the academic historians. Dramatic purposes have sometimes required many characters to be fused into one; the number of girls involved in the "crying out" has been reduced (Parker 2002, p. 83). Abigail's age has been raised and while there were several judges of almost equal authority, Miller have symbolized them in Hathorne and Danforth (p. 83). Procter's character was also developed to be one of the main characters in the play and quickly he emerges as the "center of the story Miller wished to tell" (Bigsby 1995,p. xiii). He becomes the central character whom we sympathize with and the story of the play becomes his own story (p. xv). The sexual affair between Abigail and Proctor, and Abigail's jealousy toward Elizabeth Proctor were also made up because of the dramatic necessity (p. xiv-xviii).

The literary dramatization of witchcraft or the black art that we see in Miller's play can be traced back to Renaissance drama. Christopher Marlowe's Dr. Faustus is a good example of the kind of a Renaissance tragedy, which is based on witchcraft and the black art. The only difference between Miller's The Crucible and Marlowe's Dr. Faustus is the fact that Dr. Faustus trades his Soule with the devil to practice the black art while Proctor (Miller's tragic hero) is accused with it although he has nothing to do with the devil or the black art. However, in both tragedies (Miller's and Marlowe's) the result is the tragic hero's death and the cause is supposedly a relationship between the character and the devil.

The way witchcraft is represented in the first act of Miller's tragedy is very similar to the way it was represented in Shakespeare's Macbeth. In the first scene of the fifth act of Macbeth, we see the three witches practicing their black art. The witches add some parts of living creatures (such as a frog's eye, a lizard's leg and an owlet's wing) to the kettle by which they were conjuring spirits. In the first act of The Crucible, Hale asks Abigail whether there was any living thing in the kettle they danced around in the woods. We read in act I of the play:

HALE: Mr. Parris, you did not notice, did you, any living

Thing in the kettle? A mouse, a spider, a frog-?

PARRIS: I do believe there were some movement-in the soup.

ABIGAIL: That jumped in, we never put it in

However, in Shakespeare's Macbeth, the scene of conjuring spirits happens by the three witches on the stage. In The Crucible, the dance and the spirit conjuring happen off-stage and we only know it happened because we are told by the characters themselves and not because it happens on the stage. Mr. Parris tells Hale about it when he arrived first in Salem and Abigail herself tells Proctor it happened in the first act. Abigail also confesses to Hale that it happened in the quotation above.

The themes of forgiveness and religious confession in Miller's tragedy are also themes that can be traced back to medieval and Renaissance drama. Forgiveness is a very powerful theme that appears in miracle plays in medieval drama and is not less powerful in Renaissance drama as well. This theme appears everywhere in Shakespeare's comedies and in some of his well-known tragedies as well. Forgiveness is the only thing that makes a comedy of The Tempest. Unless everybody forgives everybody at the end of the play and the lovers get married at the end of The Tempest, the play will be a perfect tragedy with distinction. Forgiveness also becomes a tool of revenge when the husband kills his wife with his unlimited and unexpected kindness and forgiveness in Heywood's A Woman Killed with Kindness.

In The Crucible, forgiveness is very powerful theme. In act II, Elizabeth Proctor cannot forget the infidelity of her husband's sin with Abigail. She cannot forget and, therefore, she cannot forgive because everybody needs to forgive something before they will be able to forget it. We read in act II:

PROCTOR: You will not judge me more,

Elizabeth. I have a good reason to think before I charged fraud on

Abigail and I will think on it.

ELIZABETH: And 1.

PROCTOR: Spare me! You forget nothin' and forgive nothin'.

In act III, Proctor goes to the court to defend the freedom of his wife, Elizabeth. While trying to demonstrate the falseness of Abigail's accusation to his wife, Proctor confesses his sin with Abigail, 
trying to show the false face of the Abigail. The judge, Hathorne, sends for Elizabeth who refuses to tell the truth of her husband's sin with Abigail, trying to save his name. Hence, Proctor's accusation of Abigail becomes the false one. Later on and after Elizabeth realizes the real trouble her husband engaged himself in to save her life and after Proctor is accused with witchcraft, she forgives him totally and she asks him for forgiveness as well. We read in act IV:

ELIZABETH: Do what you will. But let none be your judge.

There be no higher judge under Heaven than Proctor is. Forgive

Me, forgive me, John-I never knew such goodness in the world!

She covers her face, weeping.

Forgiveness, in this play, is more complicated than what one might think. Abigail accuses Elizabeth with witchcraft because she, Abigail, loves Proctor and she wants to sentence Elizabeth to death so she can get married to Proctor. What Abigail is doing here can be classified as revenge and revenge is a lack of forgiveness. Religious confession is also another theme that adds more complexity to the general theme of forgiveness in the play. Religiously speaking, if somebody makes a public confession, God will forgive him/her to whatever they have done. However, confession itself is a very complicated theme in this play. Proctor confesses his own sin with Abigail in the court, trying to save his wife's life. But, he refuses to give his signed confession document to the judge because he thinks it will ruin his name or reputation when he confessed a sin that he did not make even (witchcraft). Proctor's confession is also juxtaposed with Abigail's attitude toward her sins since she never thought even of the idea of confession.

The Crucible is also one of few modern tragedies that have a beginning, middle and an end. It is a fact that makes it very similar to Greek tragedies (Bigsby 1995, p. ix). Miller's tragedy begins with initiating the story of witchcraft and the dance in the wood. It moves to introduce us to the action gradually (complication). Proctor gets involved in the action, which reaches its "climax" by the end of act IV when proctor refuses to give the signed document of his confession to the judge. Hence, Proctor is hanged (denouement).

Miller's tragedy becomes a tragedy of a man who is brought down from fortune to misfortune and, therefore, he is a tragic hero. Proctor has committed more than one hamartia in this play. The first one happened when he committed his sin with Abigail while the second one is his own fatal pride when he refused to give the singed document of his confession to the judge at the very end of act IV. On the other hand, Proctor wins our respect for being a man in this hard situation. We read in the play:

PROCTOR: Because it is my name!

Because I cannot have another in my life! Because I lie and sign

Myself to lies! Because I am not worth the dust on the feet of

Them that hang! How may I live without my name? I have given

You my soul; leave me my name

Hale considers what Proctor has done pride and vanity saying:

HALE: Woman (Elizabeth), plead with him! It is pride

It is vanity. Be his helper! What profit him to bleed?

Shall the dust praise him? Shall the worms declare his truth?

Go to him, take his shame away!

As a matter of fact, Proctors has got all the good attributes required in a tragic hero except for the noble blood. However, the way he acts in the play makes a noble man of this farmer. Procter has confessed his own sin with Abigail in public when he did it in the court. Proctor sacrifices his own life to spare his wife's. Proctor also refuses to trade his integrity for his life, finally refuses to pay the price which is to offer the names of others to buy his life. Toward the end of act IV, Proctor says "I like not to spoil their names. I speak my own sins; I cannot judge another. I have not tongue for it." Hence he recovers his name by refusing to name others (p. xiii). Elizabeth herself recounts the goodness of her husband in act III when she was asked by the judge to speak of her husband. She says: "My husband is a good and righteous man. He is never drunk as some are, nor wastin' his time at the shovelboard. But always at his work." All in all, Proctor was carefully characterized to be a tragic hero rather than a normal modern protagonist. Therefore, proctor's character is universal rather than an individual figure. 
Inasmuch as Miller is talented in presenting a universal work, the second American to be named Nobel Literate, Eugene O'Neill, is a very brilliant playwright who is eulogized for the universality of his work. In The Great God Brown (1926), O'Neill has shown his dramatic ability as a writer who knows how to touch upon the human condition through a successful use of "Masks."The Great God Brown is a fouract play, which follows the lives of the three main characters and their relationship with each other. The protagonist is Dion Anthony, a tortured, sensitive artist, who is married to Margaret. Margret assumes a motherly role toward her husband. Billy Brown is a lifelong friend of Dion's and Margaret's who becomes a successful architect.

Masks appear in several of Eugene O'Neill's early plays, serving not as a mere technical innovation, but rather as a way to explore "hidden conflicts" of human nature (Sheaffer 1973, p. 167). In this play O'Neill flirts with masks. His characters are continuously masking and unmasking to "protect themselves from or to make contact with others." Moreover, "the playwright almost exhausting the vocabulary of the mask, also used them to indicate split personalities and to differentiate between them" (p. 167). Toward the end of act IV, Margaret finds Dion on the pier, she does not recognize him without his mask. Therefore, he is forced to put it back on.

Sheaffer also points out that the use of the mask in O'Neil's play owes to Freud and Aeschylus. He adds: "it is a new psychological insight into the human cause and effect but a study in masks, an exercise in masking?" (p. 167). The influence of Greek tragedy-itself a domain of "the masked God"which O'Neill tries to restore through several of his plays, is obvious as well. O'Neill himself talks about the symbolic nature of his characters' names. Dion Anthony is named after both Dionysius (the creative pagan acceptance of life) and St. Anthony (the masochistic life-denying spirit of Christianity). He has two opposing forces in his character (p. 168). Therefore, the mask is the only way through which Dion could balance the two opposing powers existing in his personality.

O'Neill also used historical incidents to dramatize his great piece, The Emperor Jones. The plot of this play inspired by the real story of Henri Christopher who became the king of Haiti in 1708 after the revolution he lead (Tornqvist 2004, p. 18). However, the play is not history in the sense of the word history. Like Miller's The Crucible, O'Neil's play is a literary work rather than history. Moreover, the character of Emperor Jones is carefully portrayed. Jones becomes a mythical figure. Other characters believe that Jones would not die unless he is shot with a silver bullet. The mythical power Jones has is actually related to real historical story of the king of Haiti. His people also believed that he would not die unless he is shot with a silver bullet (p. 18). At the very beginning of act VI, Jones is wondering in woods and stalked by the native, he says:

Oh, Lawd, what I gwine do now? Ain't got no bullet left on'y de silver one. If mo' o' demha'nts come after me, how I gwineskeerdem away? Oh, Lawd, on'j de silver one left —an' I gotta save datfo' luck. If I shoots dat one I'm a goner sho' I Lawd, it's black heah! Whar's de moon? Oh, Lawd, don't dis night evah come to an end?

Therefore, O'Neill is not only a great playwright who restores traditional aspect of drama, but also a talented author who knows how to dramatize historical precedents and who creates universal themes and characters. O'Neill's other plays are also full of such universal aspects. However, O'Neil also influenced other American playwrights such as his friend Susan Glaspell.

Susan Glaspell also dramatized real historical events and she composed universal themes. Glaspell started her job as a reporter right after she graduated from high school. When she graduated she worked also as a reporter to cover murder cases (Ben-Zvi 2005, p. viii). Her one act play, Trifles, is based on a story she covered as a reporter (1900-1901) to the newspaper she worked for. The plot of this tragedy is inspired from the "Hossack' murder case.A mother of nine children was accused of hatching her husband to death" (41). Glaspell decided to write her tragedy and another short story basing on this murder case. However, Glaspell dramatizes the story in her own way. She gives her character a different name and she does not use the nine children in her tragedy.

Glaspell's play starts with three men and two women entering into the Wrights' farm house. They are Mr. Hale, a neighboring farmer, and his wife, Mrs. Hale; a sheriff, Mr. Peters, and his wife; and the county attorney, Mr. Henderson. We learn that Mr. Wright was dead, with a rope slipped around his nick. The men find Mr. Wright's body upstairs. At the end the women hide the box with the bird from the men to save Mrs. Wright from being found out. The audience is left to understand that Mr. Wright 
had been abusive, and his killing of the bird had pushed Mrs. Wright to kill him. Throughout the play, women try to defend Mrs. Wright and talk about women's stuff. We read toward the end of the play:

MRS. HALE [ Her own feeling not interrupted.] If there'd been years and years of nothing, then a bird to sing to you, it would be awful--still, after the bird was still.

MRS. PETERS [ Something within her speaking.] I know what stillness is. When we homesteaded in Dakota, and my first baby died--after he was two years old, and me with no other thenMRS. HALE [Moving.] How soon do you suppose they'll be through, looking for the evidence?

MRS. PETERS I know what stillness is. [ Pulling herself back.] The law has got to punish crime, Mrs. Hale.

Another important aspect of Glaspell's work is the domestic nature of her tragedy. The tragedy happens within the family. A woman kills her husband. The domestic aspect of this play is highly important. Trifles is "a family Tragedy" just like Shakespeare's Hamlet. Kittredge defines Hamlet as "a family Tragedy" (Armens 1966, p. 117). Both tragedies happen within the family. Hence, they have effectively tragic power on the audience. This aspect is universal because we see it in different plays in different times and places. For example, Sophocles' Odipus Rex, Shakespeare's Hamlet, Othello, and King Lear and many other tragedies in Renaissance dramamight be deemed domestic tragedies. In fact, Sven Armens wrote a whole book, Archetype of the family in literature, which is dedicated to examining family tragedies. Perhaps the story Susan Glaspell dramatizesis universal by nature. However, we can say that Glaspell's theme is universal whether she means it or not.

Tennessee Williams' The glass Menagerie deals also with a universal theme. "Love leads inevitably to loss and betrayal (Parker 2002, p. 13). Even the subtheme (securing a husband) of the plot is universal. This theme is very dominant in the British novel and drama in the nineteenth century. Williams' play tells a story of an anxious mother, Amanda, who is highly worried about her daughter's future, Laura. Amanda and Tom discuss Laura's prospects, and Amanda asks Tom to keep an eye out for potential suitors at the warehouse. Tom meets Jim O'Connor, a casual friend, and invites him to dinner. As the dinner ends, Amanda takes her son and leaves Laura with Jim. Amanda confesses that she knew and liked Jim in high school but was too shy to approach him. Laura then ventures to show him her favorite glass animal, a unicorn. Jim dances with her, but in the process, he accidentally knocks over the unicorn, breaking off its horn. Laura forgives him, noting that now the unicorn is a normal horse. Jim then kisses her, but he quickly draws back and apologizes, explaining that he was carried away by the moment and that he actually has a serious girlfriend. Resigned, Laura offers him the broken unicorn as a souvenir.

The forgiveness Laura shows when Jim broke her favorite unicorn while dancing is auniversal theme we see in many plays in various time periods. Although the unicorn is dear to her heart, she forgives Jim immediately. We read in scene vii of the play:

JIM: You will never forgive me. I bet that was your favorite piece of glass.

LAURA: I don't have favorites much. It is no tragedy. Glass breaks so easily...

Therefore, Tennessee Williams' The Glass Menagerie is a black comedy, which deals with universal themes. The plot is also universal since what happens in this play might happen to everybody in different times and places. The main theme, love leads to loss and betrayal, is a universal theme we see in drama in different places and times. Forgiveness is also a universal theme that we see in different places and times in western drama in general.

Universality of American drama is also obvious in the works of other American dramatists. Edward Albee's American Dream is a good example of a play, which has universal aspects. The play tells a story of a family, Mommy, Daddy and a clever and Grandma. A neighbor, Mrs. Barker, enters and talks to Daddy and Mommy with the occasional interjection by Grandma. Mommy and Daddy exit leaving Mrs. Barker and Grandma. Grandma tells Mrs. Barker that Mommy and Daddy had adopted a son from her many years previously. As the parents objected to the child's actions, they killed the baby. After Mrs. Barker leaves, a Young Man appears at the door looking for work. After a conversation with the man, Grandma realizes that this Young Man, whom she dubs "The American Dream," is the twin of Mommy and Daddy's first child. Grandma moves her things out and leaves the house. The Young Man is introduced to the family as a suitable replacement for the original child. We read in scene vii of the play: 
GRANDMA: To the you man. Dear will you take my things out to the van?

YUON MAN: After only the briefest histation. Why certainly.

In American Dream Edward Albee's characters are very universal figures in the sense that they don't have names. These characters represent types rather than individuals. The characters in the play are called "Mommy", "Daddy" and "Grandma" and that is universal by itself. We also tend to interpret conflict in this play to be between the old and the young generations rather than a struggle between family members. Therefore, Albee's characters are universal figures rather than regular individuals. Hence, his play presents universal characters rather than regional ones.

\section{Conclusion}

As we have seen, American playwrights and drama are no less important than other international playwrights and drama. They portrayed universal characters, plots and themes. American playwrights are also no less talented than other world dramatists since they can also dramatize history. They have made great plays out of real historical precedents. They have restored many traditional themes and devices. They have written and they have portrayed scenes, whichmight be considered in dialogue with world drama. In so doing, they demonstrate theirdramatic ability since simply they have made no less important tragedies than Shakespeare's or Shaw's historical based tragedies. Therefore, American playwrights are no less talented than Shakespeare or Shaw when it comes to dramatizing historical narratives. They are no less universal when it comes to the universality of characters, plots, and themes as well. I am wondering whether my colleague or the former secretary of the Swedish Institute which awards Nobel prizes have read any American play I referred to in this essay or not. If not, I hope they read any play By O'Neil, Glaspell, Albee, Williams or Arthur Miller or at least this humble effort in defense of American drama.

\section{References}

Albee, Edward, 1960. American Dream. New York: Coward-McGann.

Armens, Sven, 1966. Archetype of the Family. Washington: The $U$ of Washington.

Ben-Zvi, Linda 2005. Glaspell: Her Life and Times. Oxford: Oxford UP.

Barnet, Sylvan 1997. Types of Drama. London: Longman.

Eliot, T.S., 1964. The Use of Poetry and the Use of Criticism. Cambridge, Harvard UP.

Glaspell, Susan 1926. Trifles and Six Other Short Plays. London: Earnest Benn.

Heywood, Thomas, 1961. A Woman Killed with Kindness. Ed, Van Fossed. London: Methuen P.

Marlowe, Christopher, 1989. Dr. Faustus. Ed: Roma Gill. London: A\&C Black.

Manheim, Ralph, 1959. Complex, Archetype, Symbol: In the Psychology of C.G. Jung. New York: Princeton UP.

Miller, Arthur, 1995. The Crucible. Ed:ChristopherBigsby. New York: Penguin Books.

O’Neill, Eugene, 1985. The Plays of Eugene O'Neill. Ed: Virginia Floyd. New York: Frederick Ungar.

Oxford Authors, 2017. Oxford English Dictionary. Oxford: Oxford UP.

Park, S. 2009. Post-humanism and the origin of Dante's universality with special reference to Canto 1 of The Paradiso: hompi.sogang.ac.kr/anthony/mesak/mes172/. P. 169-106.

Sheaffer, Louis 1973. O'Neill: Son and Artist. New York: Cooper Square.

Shakespeare, William 1970. Hamlet. Ed: G.B. Harrison. London: Penguin Books.

Shakespeare, William 1915. Macbeth. Ed: E. K.Chambers. Boston: The Arden.

Sternlicht, Sanford,2004. A Reader's Guide to Modern American Drama. New York: Syracuse UP.

Tennessee, William, 2002. The Glass Menagerie. New York: New American Library P.

Tornqvist, Egill, 2004. Eugene O'Neill. North Carolina: McFarland. 